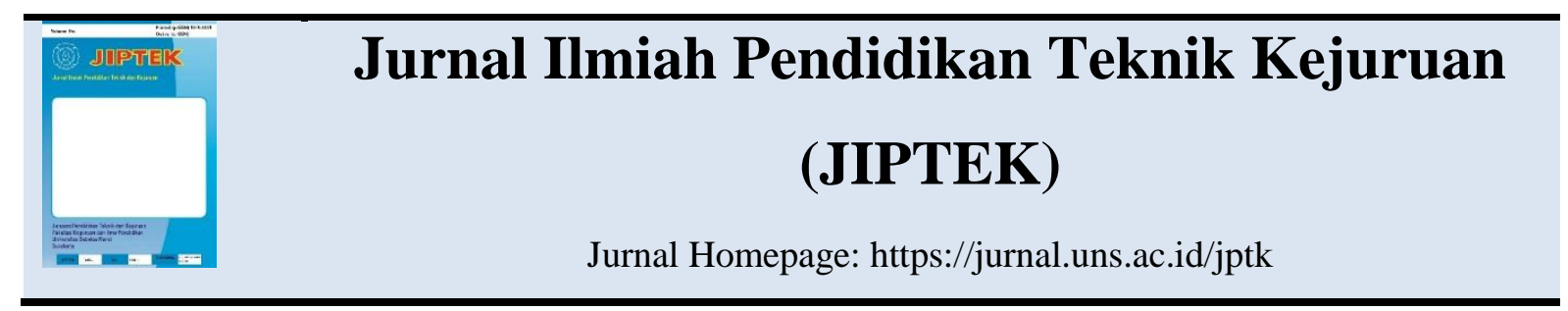

\title{
PENGARUH PEMANASAN BAHAN BAKAR MELALUI PIPA TEMBAGA BERSIRIP RADIAL DI DALAM UPPER TANK RADIATOR DAN PENAMBAHAN ETANOL PADA BAHAN BAKAR TERHADAP EMISI GAS BUANG CO DAN HC MOBIL SUZUKI APV
}

\author{
Putri Fatma Nur Sholeha, Danar Susilo Wijayanto, Ngatou Rohman \\ Program Studi Pendidikan Teknik Mesin, FKIP, Universitas Sebelas Maret Surakarta \\ Jalan Ahmad Yani 200 Surakarta \\ Email: putriefeness@gmail.com
}

\begin{abstract}
ABSTRAK
Tujuan penelitian ini adalah untuk mengetahui: (1) pengaruh pemanasan bahan bakar melalui pipa tembaga bersirip radial di dalam upper tank radiator terhadap emisi gas buang pada mobil Suzuki APV; (2) pengaruh penambahan etanol pada bahan bakar bensin pertalite terhadap emisi gas buang pada mesin bensin Suzuki APV; (3) pengaruh pemanasan bahan bakar melalui pipa tembaga bersirip radial di dalam upper tank radiator dan penambahan etanol pada bahan bakar bensin terhadap emisi gas buang pada mesin bensin Suzuki APV ; (4) perbandingan penggunaan campuran bahan bakar pertalite dan etanol dengan pertamax murni terhadap emisi ags buang mobil Suzuki APV. Penelitian ini menggunakan metode eksperimen dengan analisis data deskriptif komparatif. Data diperoleh dari emisi gas buang dengan menggunvariasi presentase campuran pertalite dan etanol $0 \%, 5 \%, 10 \%, 15 \%, 20 \%$, $25 \%$, dan $30 \%$ menggunakan metode tanpa pemanasan bahan bakar dan menggunakan pemanasan bahan bakar pipa bersirip radial dengan variasi pipa yang digunakan adalah tanpa pipa, pipa tanpa sirip, pipa dengan sirip radial jarak $30 \mathrm{~mm}, 20 \mathrm{~mm}, 10 \mathrm{~mm}$, dengan panjang pipa $550 \mathrm{~mm}$. Hasil penelitian adalah sebagai berikut ini. Pertama, pemanasan bahan bakar melalui pipa bersirip radial di dalam upper tank radiator mengakibatkan emisi gas buang $\mathrm{CO}$ dan HC menurun. Jumlah emisi terendah pada saat pemanasan bahan bakar menggunakan pipa bersirip radial dengan jarak antar sirip $10 \mathrm{~mm}$, CO sebesar 0,936 \% vol dan HC sebesar 303,33 ppm. Kedua, penambahan etanol pada pertalite dengan kadar 0\% s.d. 20\% dapat mengurangi emisi gas buang CO dan HC mobil Suzuki APV. Emisi gas buang CO dan HC paling rendah terjadi pada kadar etanol 20\%, dimana CO sebesar 0,625 \% vol dan HC 282,33 ppm. Ketiga, pemanasan bahan bakar melalui pipa bersirip radial di dalam upper tank radiator dan penambahan etanol pada pertalite mengakibatkan emisi gas buang $\mathrm{CO}$ dan $\mathrm{HC}$ menurun. Jumlah emisi terendah pada saat pemanasan bahan bakar melalui pipa bersirip radial jarak $10 \mathrm{~mm}$ dan penambahan etanol dengan kadar 20\%, dimana CO sebesar 0,333 \% vol dan HC sebesar 240 ppm.
\end{abstract}

Kata Kunci: pipa bersirip radial, etanol, mesin bensin, EFI, emisi gas buang CO dan HC

PENDAHULUAN

Pada era globalisai saat ini mobilitas manusia sangat menjadi hal penting sebagai penunjang kebutuhan dalam kehidupan seharihari. Salah satu keperluan mobilitas manusia yaitu dengan adanya alat transportasi. Di Indonesia, seiring 
dengan perkembangan jumlah penduduk maka semakin banyak permintaan produksi kendaraan. Indonesia menjadi pangsa pasar yang sangat potensial bagi penjualan kendaraan berbagai jenis dan merk, hal ini dapat dilihat dari besarnya tingkat pertumbuhan kendaraan bermotor meningkat setiap tahunnya. Dari data BPS (Badan Pusat Statistik), pada tahun 2006 jumlah produksi kendaraan bermotor sebanyak 4.754.894 buah. Setelah kurun waktu 3 tahun yaitu pada tahun 2009 memproduksi sebanyak 6.348.837 buah. Sementara pada tahun 2013 jumlah produksi sebanyak 8.988.506 buah. Hal ini membuktikan bahwa tiap tahun produksi kendaraan bermotor meningkat.

Menurut Soedomo (2001) tingkat pertumbuhan kendaraan bermotor mempunyai dampak positif mendorong tingkat pertumbuhan ekonomi, akan tetapi juga memiliki dampak negatif yaitu dampak terhadap lingkungan. Dampak lingkungan yang ditimbulkan antara lain kemacetan, kebisingan, dan polusi udara akibat emisi gas buang hasil pembakaran. Saat ini emisi gas buang kendaraan menjadi faktor paling dominan dari polusi udara. Sumber polusi yang utama berasal dari transportasi, yakni hampir $60 \%$ dari polutan yang dihasilkan terdiri dari karbon monoksida dan sekitar $15 \%$ terdiri dari hidrokarbon (Srikandi, 1992: 93).

Mengetahui tingginya emisi gas buang dan dampak buruk yang ditimbulkan, maka perlu suatu upaya untuk menanggulangi untuk mengurangi dampak buruk dari emisi gas buang terhadap kesehatan makhluk hidup terutama manusia. Beralihnya sistem karburasi ke sistem EFI (Electric Fuel Injection) merupakan salah satu upaya untuk menurunkan emisi gas buang karena lebih ramah lingkungan. Upaya lainnya dengan cara menaikkan suhu bahan bakar dan peningkatan nilai oktan. Menaikkan suhu bahan bakar dapat dilakukan dengan pemanasan bahan bakar, sehingga saat bahan bakar bercampur dengan udara akan lebih cepat menguap. Bahan bakar yang mudah menguap akan lebih mudah terbakar, sehingga pembakaran dapat terjadi secara sempurna. Metode pemanasan bahan bakar menggunakan media pipa tembaga bersirip radial yang dapat dilakukan dengan memanfaatkan sirkulasi air pendingin radiator. Pemanfaatan sirkulasi air pendingin radiator dapat dilakukan pada upper tank radiator. Penggunaan upper tank radiator dikarenakan suhu yang berada pada upper tank lebih tinggi daripada di lower tank radiator.

Cara lain untuk dengan meningkatkan nilai oktan yaitu dengan cara penambahan etanol. Nilai oktan yang terkandung di dalam bahan bakar setelah adanya etanol akan meningkat. Meningkatnya nilai oktan ini secara tidak langsung berpengaruh terhadap pembakaran yang sempurna (Sugiyarto, 2011). Proses pembakaran yang sempurna tersebut akan mempengaruhi gas buang hasil pembakaran. Saat ini 
upaya pengurangan kadar emisi gas buang dengan metode pemanasan bahan bakar masih kurang intensif. Penelitian lebih lanjut tentang pemanasan bahan bakar sangat diperlukan. (Raja., dkk, 2015)

\section{METODE PENELITIAN}

Sampel penelitian ini adalah mesin bensin Suzuki APV GL dengan nomer rangka $\mathrm{MH}$ YGDN41V00100006 dan nomor mesin G15A1D100006. Pengambilan sampel menggunakan purposive sampling atau sampel bertujuan. Variabel bebas dalam penelitian ini adalah Pemanasan bahan bakar melalui pipa tembaga tanpa sirip dan bersirip radial di dalam upper tank radiator dengan sirip radial berjarak $10 \mathrm{~mm}$, sirip radial berjarak $20 \mathrm{~mm}$, dan sirip radial berjarak $30 \mathrm{~mm}$ serta Campuran bahan bakar pertalite dan etanol dengan variasi kadar bioetanol 0\%, $5 \%, 10 \%, 15 \%, 20 \%, 25 \%, 30 \%$, dan pertamax $92 \quad 100 \%$ tanpa campuran. Sedangkan variabel terikatnya adalah emisi gas buang $\mathrm{CO}$ dan $\mathrm{HC}$ dari mesin bensin Suzuki APV. Metode pengumpulan data penelitian ini adalah metode pengukuran dan teknik analisis data yang digunakan adalah deskriptif komparatif. Prosedur penelitian ini adalah variasi campuran bahan bakar di tempatkan sebelum saringan bahan bakar kemudian menuju pompa bahan bakar yang selanjutnya disalurkan ke pipa tembaga yang berada di dalam upper tank radiator, setelah dari pipa, bahan bakar disalurkan ke injektor yang kemudian menuju ruang bakar. Pengukuran emisi dilakukan sesuai dengan SNI 19-7118.12005.

\section{HASIL PENELITIAN DAN}

\section{PEMBAHASAN}

Berikut adalah data dari hasil pengujian pemanasan bahan bakar dan penambahan etanol terhadap emisi gas buang $\mathrm{CO}$ dan $\mathrm{HC}$ pada mobil Suzuki APV.

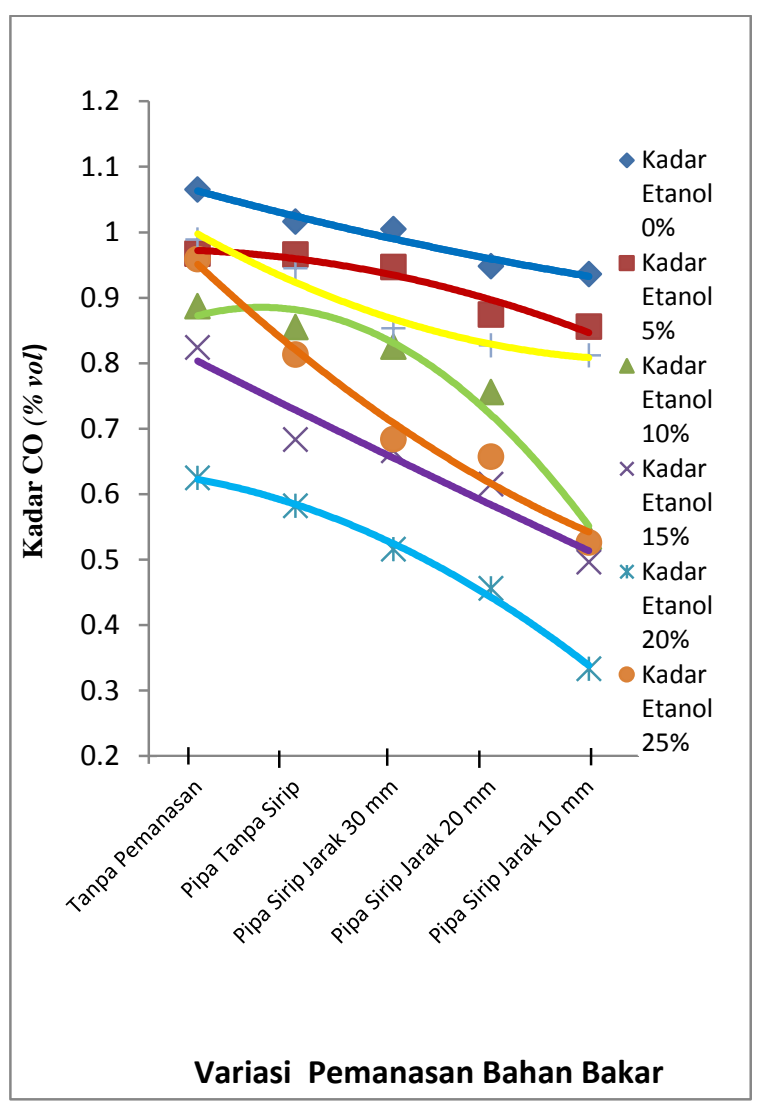

Gambar 1. Pengaruh Pemanasan Bahan Bakar terhadap Emisi Gas Buang CO 


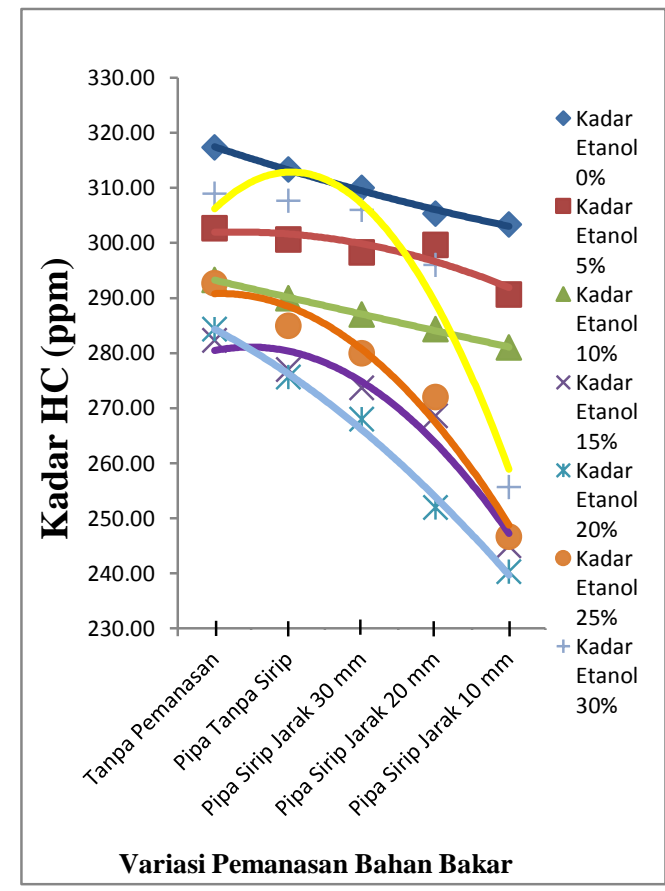

Gambar 2. Pengaruh Pemanasan Bahan Bakar terhadap Emisi Gas Buang HC

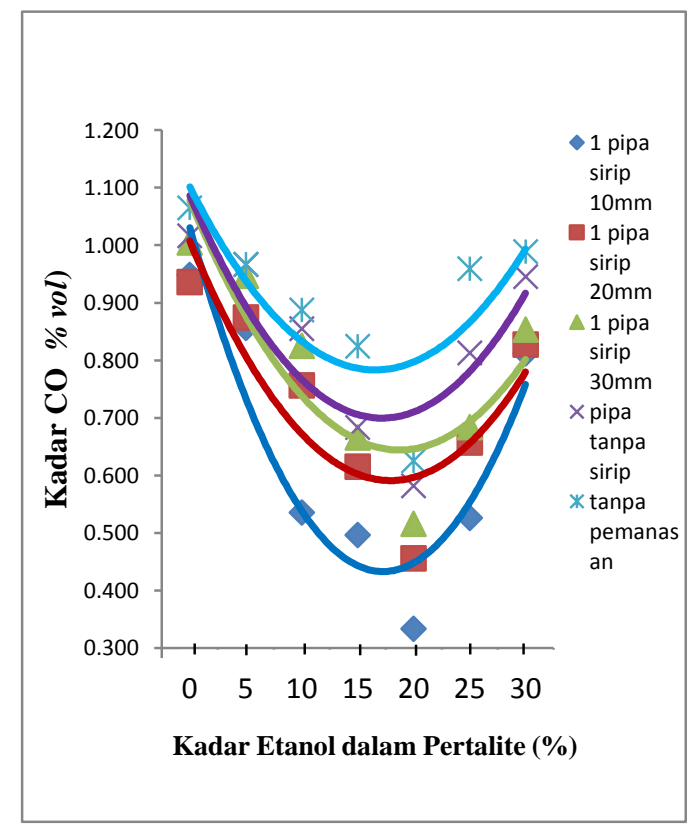

Gambar 3. Pengaruh Kadar Etanol terhadap Emisi Gas Buang CO

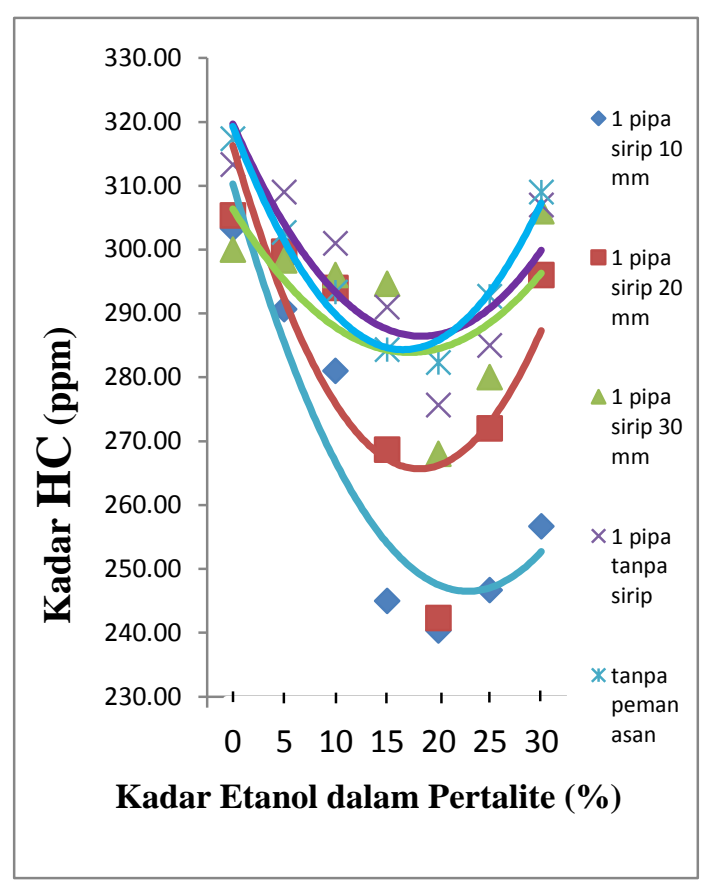

Gambar 4. Pengaruh Kadar Etanol terhadap Emisi Gas Buang HC

\section{PEMBAHASAN}

\section{Pemanasan Bahan Bakar dan Penambahan Etanol terhadap Emisi Gas Buang CO}

Berdasarkan gambar 1., gambar 2., gambar 3., dan gambar 4., menunjukkan pengaruh pemanasan bahan bakar melalui pipa bersirip radial dan penambahan etanol dalam pertalite terhadap emisi gas buang $\mathrm{CO}$ dan $\mathrm{HC}$ berdasarkan pengujian yang telah dilakukan. Data tersebut menunjukkan emisi gas buang standar pada mobil Suzuki APV kadar CO sebesar 1,065 $\%$ vol dan HC sebesar 317,33 ppm

\section{Pemanasan Bahan Bakar terhadap Emisi Gas Buang HC}


Pada gambar 1. Dan gambar 2., dapat dilihat bahwa pemanasan bahan bakar dapat menurunkan emisi gas buang $\mathrm{CO}$ dan HC, dimana kadar emisi terendah didapatkan pada saat pemanasan bahan bakar dengan 1 pipa tembaga bersirip radial dengan jarak antar sirip $10 \mathrm{~mm}$ yaitu $\mathrm{CO}$ sebesar 0,936 \% vol dan HC sebesar 303,33 ppm. Hal tersebut terjadi karena panas yang diserap oleh pemanasan menggunakan 1 pipa bersirip radial membuat bahan bakar yang mempunyai rantai karbon penyusun bahan bakar dari molekul kurang baik (rantai karbon lurus) menjadi rantai karbon bercabang lebih banyak. Semakin banyak jumlah sirip pada pipa tembaga bersirip radial membuat suhu bahan bahan bakar meningkat. Semakin suhu bahan bakar meningkat membuat cabang rantai karbon pada bahan bakar semakin banyak, sehingga bahan bakar lebih mudah bercampur dengan udara yang masuk ke dalam silinder.

Pemanasan bahan bakar meningkatkan suhu bahan bakar yang mengakibatkan bahan bakar lebih mudah menguap. Pemanasan bahan bakar mempercepat bahan bakar berubah menjadi fase uap. Percepatan fase uap pada bahan bakar dapat mengakibatkan homogenitas bahan bakar meningkat dan pembakaran menjadi lebih sempurna, maka nilai emisi $\mathrm{CO}$ dan $\mathrm{HC}$ akan menurun. Homogenitas campuran bahan bakar dan udara akan baik.
Homogenitas campuran yang semakin baik membuat sistem pembakaran yang semakin baik, sehingga dapat menurunkan emisi gas buang $\mathrm{CO}$ dan $\mathrm{HC}$.

Pembakaran bahan bakar yang sempurna adalah yang memiliki tingkat homogenitas yang tinggi ( Wijayanto., dkk, 2014). Homogenitas campuran sangat dipengaruhi oleh AFR yang ideal. AFR yang ideal adalah memiliki nilai lambda 1 . Lambda adalah perbandingan AFR secara teoretis dan praktis, maksudnya adalah semisal teori menyebutkan bahwa AFR ideal adalah 14,7: 1, maka dalam hasil uji emisi akan menunjukkan bahwa lambda suatu kendaraan adalah 1 (Sudibyo, 2009). Campuran bahan bakar dan udara yang miskin memiliki nilai lambda > 1 , campuran bahan bakar dan udara yang kaya memiliki nilai lambda $<1$.

Pada rata-rata pengambilan data menunjukkan nilai lambda lebih dari 1 . Kadar CO maksimum dihasilkan saat motor beroperasi dengan campuran kaya, seperti saat mulai dinyalakan, pada kondisi dingin, atau percepatan., dan ketika AFR miskin kadar CO akan berkurang (Kristanto, 2015: 201). AFR yang terlalu kaya akan menyebabkan HC menjadi tinggi (Sudibyo, 2009: 14).

\section{Kadar Etanol terhadap Emisi Gas Buang CO dan HC}

Pada gambar 3. Dan gambar 4., dapat dilihat bahwa penambahan etanol 0\%-20\% 
dapat menurunkan kadar emisi gas buang CO dan HC, dimana emisi terbaik atau yang kadar emisi paling rendah didapatkan pada campuran etanol $20 \%$ yaitu kadar CO sebesar 0,333 \% vol dan HC sebesar 240,33 ppm. Hal tersebut terjadi karena penambahan etanol dalam pertalite mengakibatkan bilangan oktan meningkat. Penambahan etanol pada bahan bakar akan menyebabkan meningkatnya angka oktan pada bahan bakar (Dharu, 2017). Setiap penambahan etanol sebanyak $10 \%$ akan meningkatkan angka oktan sebesar 5\% (Raja,dkk, 2015).

Penambahan etanol pada bahan bakar pertalite berpengaruh terhadap emisi gas buang mobil Suzuki APV dimana penambahan etanol dengan kadar tertentu akan menyebabkan emisi gas buang menurun. Dari data yang didapat emisi gas buang paling rendah diperoleh pada campuran bahan bakar dengan kadar etanol $20 \%$ yaitu sebanyak 0,625\% vol. Emisi gas buang mengalami penurunan seiring penambahan etanol dari kadar 0\% s/d 20\% namun emisi gas buang kembali mengalami kenaikan pada kadar etanol 25\% dan 30\%.

Data emisi gas buang $\mathrm{HC}$ paling rendah diperoleh pada campuran bahan bakar dengan kadar etanol 20\% yaitu sebanyak 282,33 ppm. Terjadi penurunan emisi gas buang sebesar $35 \mathrm{ppm}$ atau $11 \%$ dari emisi gas buang dengan campuran etanol $0 \%$. Emisi gas buang mengalami penurunan seiring penambahan etanol dari kadar 0\% s/d 20\% namun emisi gas buang kembali mengalami kenaikan pada kadar etanol $25 \%$ dan $30 \%$.

Penurunan emisi gas buang tersebut terjadi karena penambahan etanol dalam kadar tertentu pada bahan bakar pertalite mengakibatkan bilangan oktan bahan bakar meningkat. Semakin tinggi nilai oktan maka kemampuan pembakaran bahan bakar akan lebih efisien. Setiap penambahan $10 \%$ etanol pada bahan bakar dapat menaikkan oktan sebesar 5\% (Raja, dkk., 2105). Jika pembakaran lebih sempurna maka bahan bakar akan terbakar lebih sempurna. Pada penelitian ini penambahan etanol yang paling efektif pada penambahan etanol kadar 20\%. Sedangkan pada penambahan etanol dengan kadar $25 \%$ dan $30 \%$ akan mengakibatkan emisi gas buang meningkat, hal tersebut karena nilai oktan yang terkandung dalam bahan bakar terlalu tinggi sehingga pembakaran menjadi tidak sempurna yang mengakibatkan emisi meningkat. Semakin tinggi nilai oktan bahan bakar maka semakin susah untuk terjadi pembakaran, maka diperlukan pula rasio kompresi yang sesuai dengan nilai oktan bahan bakar yang digunakan (Ahmad, 2015: 56). Waktu pengapiannya menjadi tidak sesuai atau campuran bahan bakar dan udara tidak meledak dengan sempurna. Jika bahan bakar tidak terbakar 
sempurna maka akan meningkatkan nilai emisi gas buang.

\section{SIMPULAN DAN SARAN}

\section{Simpulan}

Berdasarkan hasil analisis data dan pembahasan dapat diambil simpulan sebagai berikut:

1. Pemanasan bahan bakar pertalite di dalam pipa bersirip radial melalui upper tank radiator pada mobil injeksi Suzuki APV menurunkan nilai emisi gas buang $\mathrm{CO}$ dan $\mathrm{HC}$. Nilai emisi gas buang $\mathrm{CO}$ paling rendah terjadi pada penerapan pipa bersirip jarak $10 \mathrm{~mm}$ sebesar 0,936 \% vol dan HC sebesar 303,33 ppm.

2. Penambahan etanol pada bahan bakar pertalite dengan kadar $0 \%$ sampai dengan $20 \%$ terjadi penurunan nilai emisi gas buang $\mathrm{CO}$ dan HC. Emisi gas buang $\mathrm{CO}$ dan HC kembali meningkat pada kadar pencampuran etanol dengan kadar $25 \%$ dan $30 \%$. Nilai gas buang CO dan $\mathrm{HC}$ yang paling rendah terdapat pada penambahan etanol kadar $20 \%$ yaitu CO sebesar 0,625 \% vol dan HC 282,33 ppm.

3. Pemanasan bahan bakar pertalite di dalam pipa bersirip radial dengan penambahan etanol terjadi penurunan nilai emisi gas buang $\mathrm{CO}$ dan HC pada pencampuran kadar etanol. Nilai emisi gas buang terendah terjadi pada pipa bersirip radial jarak $10 \mathrm{~mm}$ dengan kadar etanol $20 \%$ yaitu CO sebesar 0,333 $\%$ vol dan HC sebesar 240 ppm.

4. Kadar emisi pada pemanasan bahan bakar terbaik yaitu pada pipa bersirip radial jarak $10 \mathrm{~mm}$ pertalite dengan kadar etanol 20\% lebih rendah dari penggunaan pertalite tanpa pemanasan dengan nilai $\mathrm{CO}$ sebesar $0,333 \%$ vol dan HC sebesar 240,33 ppm. Kadar emisi terendah pada penggunaan pertamax dengan nilai $\mathrm{CO} \quad 0,352 \%$ vol dan $\mathrm{HC}$ sebesar 303,33 ppm.

\section{Saran}

Berdasarkan simpulan dan implikasi hasil penelitian, maka dapat dikemukakan saran sebagai berikut:

1. Bagi para pemilik kendaraan roda empat berteknologi EFI khususnya Suzuki APV dapat menggunakan bahan bakar campuran Pertalite dan etanol dengan kadar 20\% dengan spesifikasi kadar etanol sama dengan penelitian ini untuk menurunkan emisi gas buang pada mobil Suzuki APV.

2. Bagi peneliti yang ingin mengembangkan penelitian ini, hendaknya memperhatikan rasio kompresi pada kendaraan yang digunakan. Misal dengan cara memodifikasi ruang bakar. 
3. Bagi peneliti yang ingin mengembangkan penelitian ini,hendaknya melakukan pengukuran nilai oktan agar diketahui nilai kenaikan oktan secara pasti.

4. Bagi peneliti yang ingin mengembangkan penelitian ini, hendaknya melakukan pengujian torsi dan daya untuk mengetahui pengaruh unjuk kerja mesin terhadap emisi gas buang.

\section{DAFTAR PUSTAKA}

Anonim. Produksi Kendaraan Bermotor Dalam Negeri (unit), 2008-2013 diakses pada tanggal 15 Februari 2017 , dari ttps://www.bps.go.id/linkTabelStat is/view/id/1065

Fardiaz Srikandi. (1992). Polusi Air \& Udara,. Bogor: Penerbit Kanisius.

Jayanti, E.S., dkk. (2006). Emisi Gas Carbon Monooksida (CO) Dan Hidrocarbon (Hc) pada Rekayasa Jumlah Blade Turbo Ventilator Sepeda Motor "Supra X 125 Tahun 2006. ROTASI Jurnal Teknik Mesin UNDIP. Diperoleh pada 15 Mei 2017, dari http://ejournal.undip.ac.id/index.p $\mathrm{hp} /$ rotasi

Kristanto, Philip. (2015). Motor Bakar Torak Teori \& Aplikasinya. Yogyakarta: CV.ANDI

Raja,dkk (2015). Effect of Gasoline Ethanol Blends on Performance and Emission Characteristics of a Single Cylinder Air Cooled Motor
Bike Si Engine. Journal of Engineering Science and Technology Diperoleh pada tanggal 20 Juni 2017 dari http://jestec.taylors.edu.my

Sanata, Andi. (2012). Optimalisasi Prestasi Mesin Bensin dengan Variasi Temperatur Campuran Bahan Bakar Premium dan Etanol. Jurnal Rotor Teknik Mesin Universitas Jember Vol. 5 Nomor 2. Diperoleh pada tanggal 25 Juli 2017 pada jurnal.unej.ac.id/index.php/RTR

Seto, Dharu (2017). Pengaruh Penggunaan Etanol terhadap Bahan Bakar Premium Untuk Unjuk Kerja Mesin Bensin. Diperoleh pada 12 Juni 2017 dari http://etd.repository.ugm.ac.id/

SNI 19-7118.1-2005 tentang Pengukuran Emisi Gas Buang Kendaraan Bermotor.

Soedomo, Moestikahanadi. (2001). Pencemaran Udara. Bandung: Penerbit ITB.

Sudibyo, Agus. (2009). Hubungan Perubahan Temperatur Air Pendingin terhadap Debit Penyemprotan Bahan Bakar Injeksi dan Emisi Gas Buang. Diperoleh pada 15 Juli 2017, dari jurnal.unigamalang.ac.id/

Sugiyarto. (2011). Pengaruh Pemanasan Bahan Bakar Bensin melalui Media Pipa Tembaga di dalam Upper Tank Radiator terhadap Emisi Gas Buang Karbon Monoksida (CO) pada Mesin Daihatsu Taruna Tahun 2000. Diperoleh pada tanggal 15 Juli 2017 dari jurnal.fkip.uns.ac.id

Wardono, H. (2004). Modul Pembelajaran Motor Bakar 4-Langkah. Jurusan Teknik Mesin. Universitas Bandar Lampung. Bandar Lampung 
Wijayanto, Danar S., dkk. (2013). Analisis Penerapan Heat Transfer pada Pemanasan Bahan Bakar Bensin melalui Pipa Kapiler Bersirip di dalam Upper Tank Radiator untuk Meningkatkan Performansi Mesin Kijang. JIPTEK, 7(2), 76-92.

Wijayanto, Danar S., dkk. (2014). Pengaruh Pemanasan Bahan Bakar melalui Pipa Bersirip Transversal pada Upper Tank Radiator dan Penambahan Etanol terhadap Emisi Gas Buang pada Toyota Kijang JIPTEK, 7(2), 25-33.

Wijayanto, D.S., dkk. (2016). Preliminary Experiment on Fuel Consumption and Emission Reduction in SI Engine Using Blended Bioethanol-Gasoline and Radiator Tube-Heater. International Journal of Sustainable Engineering. Diperoleh pada 13 Februari 2017, dari http://dx.doi.org/10.1080/1939703 8.2016 .1264497

PT. Indomobil Suzuki International. 2003. Manual Book Suzuki APV PT. Indomobil Suzuki International. 